\title{
Seroprevalence of Toxoplasma gondii infection among women of childbearing age in an endemic region of Romania, 2016-2018
}

\author{
Alin Gabriel Mihu ${ }^{1,2,3, *}$, Cornel Balta ${ }^{3}$, Daniela Teodora Marti ${ }^{3}$, Ana Alexandra Paduraru ${ }^{1,4,6}$, \\ Maria Alina Lupu ${ }^{1,5,6}$, and Tudor Rares Olariu ${ }^{1,4,6, *}$ \\ ${ }^{1}$ Discipline of Parasitology, Victor Babes University of Medicine and Pharmacy, Piata Eftimie Murgu, \\ No. 1, 300041 Timisoara, Romania \\ ${ }^{2}$ Bioclinica, Dreptatii Street, No. 23, B1. 707, 310300 Arad, Romania \\ 3 Vasile Goldis Western University, Liviu Rebreanu Street, No. 86, 310048 Arad, Romania \\ ${ }^{4}$ Clinical Laboratory, Municipal Clinical Emergency Hospital, Strada Gheorghe Dima Nr. 5, 300254 Timisoara, Romania \\ ${ }^{5}$ Clinical Laboratory, Institute of Cardiovascular Diseases, Strada Gheorghe Adam Numarul 13A, 300310 Timisoara, Romania \\ ${ }^{6}$ Center for Diagnosis and Study of Parasitic Diseases, Victor Babes University of Medicine and Pharmacy, Piata Eftimie Murgu, \\ No. 1, 300041 Timisoara, Romania
}

Received 28 July 2020, Accepted 24 October 2020, Published online 16 November 2020

\begin{abstract}
Toxoplasmosis is an important worldwide zoonosis caused by the protozoan parasite Toxoplasma gondii. This parasitic infection is often asymptomatic in immunocompetent people. However, if the infection occurs in pregnant women, it can have serious consequences for the foetus. In this study, we evaluated the seroprevalence of T. gondii in women of childbearing age in Arad County, Western Romania. Serum samples from 2626 women were analysed using a Siemens ADVIA Centaur XP Immunoassay System. Toxoplasma gondii IgG antibodies were demonstrated in 1081 women (41\%) and prevalence tended to increase with age, from 32\% in women aged 15-19 years to $62 \%$ in women aged $40-45$ years. There was a higher prevalence in rural areas (46\%) than in urban areas (36\%). This study provides new data on $T$. gondii seroprevalence in women of childbearing age from Western Romania.
\end{abstract}

Key words: Toxoplasmosis, Women of childbearing age, Laboratory diagnosis, Seroprevalence.

\begin{abstract}
Résumé - Séroprévalence de l'infection à Toxoplasma gondii chez les femmes en âge de procréer dans une région endémique de la Roumanie, 2016-2018. La toxoplasmose est une zoonose mondiale importante causée par le parasite protozoaire Toxoplasma gondii. Cette infection parasitaire est souvent asymptomatique chez les sujets immunocompétents. Cependant, si l'infection survient chez la femme enceinte, elle peut avoir de graves conséquences pour le fœtus. Dans cette étude, nous avons évalué la séroprévalence de $T$. gondii chez les femmes en âge de procréer dans le comté d'Arad, dans l'ouest de la Roumanie. Des échantillons de sérum de 2626 femmes ont été analysés avec le Siemens ADVIA Centaur XP. Des anticorps IgG contre $T$. gondii ont été mis en évidence chez 1081 femmes $(41 \%)$ et la prévalence avait tendance à augmenter avec l'âge, passant de $32 \%$ chez les femmes âgées de 15 à 19 ans à $62 \%$ chez les femmes âgées de 40 à 45 ans. La prévalence était plus élevée dans les zones rurales $(46 \%)$ que dans les zones urbaines $(36 \%)$. Cette étude fournit de nouvelles données sur la séroprévalence de $T$. gondii chez les femmes en âge de procréer de l'ouest de la Roumanie.
\end{abstract}

\section{Introduction}

Toxoplasma gondii is a single-celled, obligate intracellular protozoan parasite. Contact with this parasite causes the infection called toxoplasmosis. In humans, the infection is transmitted either by ingestion of food or water contaminated with oocysts or by eating undercooked or raw meat that contains tissue cysts [13]. Usually, in immunocompetent individuals, toxoplasmosis remains asymptomatic and undiagnosed. If T. gondii primary infection occurs during pregnancy, this

*Corresponding authors: alinmg@yahoo.com; rolariu@yahoo.com parasite may cause congenital infection with devastating consequences to the infected child, including chorioretinitis, blindness, cerebral calcifications, hydrocephalus, microcephaly, or developmental delay. Due to the severe complications of congenital toxoplasmosis, the seroprevalence of $T$. gondii in women of childbearing age should be monitored $[2,16,18]$.

Seroprevalence of $T$. gondii IgG antibodies in women of childbearing age varies between countries and sometimes between regions within a country, ranging from $4 \%$ in South Korea to $84 \%$ in Madagascar [6]. A higher rate of latent toxoplasmosis has been associated with low-income, developing countries [23]. Developing countries in Africa report a 
Table 1. Seroprevalence of Toxoplasma gondii infection in women of childbearing age according to age and area of residence.

\begin{tabular}{|c|c|c|c|c|}
\hline \multirow[t]{2}{*}{ Age (years) } & \multicolumn{3}{|c|}{ No. positive/No. investigated (\%) } & \multirow[t]{2}{*}{$p$-values } \\
\hline & Urban & Rural & Overall & \\
\hline $15-19$ & $4 / 18(22.22 \%)$ & $14 / 38(36.84 \%)$ & $18 / 56(32.14 \%)$ & - \\
\hline $20-24$ & $49 / 128(38.28 \%)$ & $111 / 283(39.22 \%)$ & $160 / 411(38.92 \%)$ & 0.28 \\
\hline $25-29$ & $155 / 442(35.06 \%)$ & $270 / 551(49.00 \%)$ & $425 / 993(42.79 \%)$ & 0.18 \\
\hline $30-34$ & $148 / 428(34.57 \%)$ & $131 / 277(47.29 \%)$ & $279 / 705(39.57 \%)$ & 0.27 \\
\hline $35-39$ & $83 / 235(35.31 \%)$ & $68 / 148(45.94 \%)$ & $151 / 383(39.42 \%)$ & 0.28 \\
\hline $40-45$ & $28 / 42(66.66 \%)$ & $20 / 36(55.55 \%)$ & $48 / 78(61.53 \%)$ & 0.03 \\
\hline Total & $467 / 1293(36.11 \%)$ & $614 / 1333(46.06 \%)$ & $1081 / 2626(41.16 \%)$ & - \\
\hline
\end{tabular}

high prevalence. In Ethiopia, for example, seroprevalence of $T$. gondii $\mathrm{IgG}$ antibodies in women of childbearing age is as high as $78.4 \%$ [8], and in Cameroon the seroprevalence of these antibodies is 54\% [26]. In highly industrialised countries such as the United States, seroprevalence of $T$. gondii $\operatorname{IgG}$ antibodies is around $9 \%$ [10].

The overall seroprevalence of $T$. gondii $\operatorname{IgG}$ antibodies in Europe, in women of childbearing age, was estimated at $23 \%$ in 2014 [6]. Seroprevalence varies in different countries: $37 \%$ in France [14], 25.9\% in Germany [27], 33\% in Serbia [22], and $29.1 \%$ in Croatia [25].

In Romania, there is a lack of knowledge on the current epidemiological situation regarding toxoplasmosis, because only small-scale studies have been performed until now. In addition, no national screening programme for pregnant women and congenital toxoplasmosis have been implemented. Previous reports have shown that $T$. gondii infection is endemic in Western Romania [15, 17]. However, no studies regarding $T$. gondii seroprevalence have been conducted among women of childbearing age in Arad County, Western Romania. Therefore, we decided to assess the seroprevalence of $T$. gondii infection in women of childbearing age from this region.

\section{Materials and methods}

We investigated serum samples collected from 2626 women of childbearing age. The women were 15-45 years of age and were residents of Arad County, which has a population of 409,072 inhabitants. Samples were collected from 01 January 2016 to 31 December 2018, and no clinical criteria were used to include individuals in this study.

Women were grouped into six categories based on their age when the sample was drawn: 15-19 years, 20-24 years, 25-29 years, 30-34 years, 35-39 years, and 40-45 years.

Serum samples were screened for $\operatorname{IgG}$ anti- $T$. gondii antibodies using ADVIA Centaur ${ }^{\circledR}$ XP (Siemens Healthcare Diagnostics, USA), according to the manufacturer's instructions and internal laboratory standards. This test detects IgG antibodies using a chemiluminescence method. A value above $10 \mathrm{IU} / \mathrm{mL}$ was considered positive, inconclusive values ranged between 6.4 and $10 \mathrm{IU} / \mathrm{mL}$, and values below $6.4 \mathrm{IU} / \mathrm{mL}$ were negative. For the purposes of this study, inconclusive values were considered negative.

Data were collected using Microsoft Excel, version 2011 (Microsoft Corp., Redmond, WA, USA), and statistical analyses were performed with the Epi Info statistical package 3.3.2 (Centers for Disease Control and Prevention, Atlanta, GA, USA). Mantel-Haenszel chi-square and two-tailed Fisher's exact tests were used for comparison between groups. A $p$-value of $<0.05$ was considered statistically significant.

This study was approved by the Victor Babes University Ethics Committee, Timisoara, Romania.

\section{Results}

Toxoplasma gondii IgG antibodies were found in 1081 of 2626 females (41.16\%), and the prevalence tended to increase with age. A statistically significant higher seroprevalence was observed in women $40-45$ years old $(61.53 \%)$ when compared to those $15-19$ years $(32.14 \%)$ ( $p=0.03)$. No statistically significant difference in seroprevalence was found when we compared women 15-19 years $(32.14 \%)$ with those 20-24 years $(38.92 \%)(p=0.28), 24-29$ years $(42.79 \%)$ $(p=0.18), 30-34$ years $(39.57 \%)(p=0.27)$, and $35-39$ years $(39.42 \%)(p=0.28)$ (Table 1$)$. When data were analysed according to the area of residence (urban or rural) a higher seroprevalence of $\mathrm{IgG}$ antibodies was found in women from rural areas $(46.06 \%, 614 / 1333)$ when compared to women from urban areas $(36.11 \%, 467 / 1293)(p=0.001)$ (Table 1).

The $T$. gondii $\operatorname{IgG}$ antibodies seroprevalence tended to increase with age in both rural and urban areas.

\section{Discussion}

This study demonstrated the presence of $T$. gondii $\operatorname{IgG}$ antibodies in serum samples of $41.16 \%$ of women of childbearing age living in Arad county, a well-known endemic area of Romania. The seroprevalence was higher than that reported by other European investigators: $24.1 \%$ in Northern Kosovo and Metohija [22], 22.3\% in Italy [5], 22\% in Portugal [7], and $29.1 \%$ in Croatia [25]. The differences in seroprevalence of $T$. gondii $\mathrm{IgG}$ antibodies between countries can be explained by different nutritional habits, as well as sociodemographic and cultural factors $[17,19]$. However, seroprevalence of $T$. gondii infection in our study was lower than the $57.6 \%$ reported in women of childbearing age from Timis county, Romania, one of the neighbouring counties [15]. Toxoplasma gondii seroprevalence may vary within a country and sometimes between different communities in one region $[17,20]$. We have no explanation for this difference because participants were not 
interviewed regarding additional risk factors such as meat consumption, contact with cats or soil, occupation, economic status, or education level. It is possible that some of these potential exposure factors could contribute to the difference in $T$. gondii seroprevalence between Arad and Timis counties.

In the current study, the seroprevalence was higher in women from rural areas (46.06\%) compared to those from urban areas $(36.11 \%)$. Similar findings were reported by Olariu et al. and Vilibic-Cavlek et al. $[15,25]$. This can be explained by the activities carried out in rural areas which may expose individuals to contaminated water or soil [24]. Farming, gardening, and handling animals are factors that may contribute to a higher prevalence in women residing in rural areas [12]. Prevalence rates are influenced by geographic differences and may be explained by exposure to the main sources of infection: tissue cysts acquired from undercooked meat, or oocysts found in soil contaminated by cat faeces. Feral cats that defecate in gardens or sandboxes may pose a risk of $T$. gondii infection in some people, regardless of whether they own a cat $[1,3,9,11]$.

As previously reported by other authors, seroprevalence of T. gondii infection in our study showed an age-related increase, with lower rates found in younger women. This type of association probably occurred due to longer exposure to the risk factors associated with $T$. gondii infection [19, 21].

No epidemiological investigations or questionnaires were conducted in this study. However, a seroprevalence of $70 \%$ of $T$. gondii antibodies was previously reported in cats in Western Romania, which may contribute to the high seroprevalence in our studied group [4].

The present study brings new epidemiological information on the prevalence of $T$. gondii infection in women of childbearing age from Arad County, Western Romania. Our results indicate a high prevalence of $T$. gondii infection in this study group. Further studies should be conducted to determine the main risk factors that contribute to such seroprevalence. This knowledge is vital to predict and prevent the risk of infection in pregnant women in the future. The serological status of women of childbearing age provides valuable information on immunity, which may help to prevent congenital infection by identifying women at risk. Our findings may serve as a starting point for counselling and education programmes on toxoplasmosis in antenatal clinics, and for the implementation at the national level of a screening and prevention programme for pregnant women.

\section{Declaration of interest}

The authors report that they have no conflicts of interest. The authors alone are responsible for the content and writing of the paper.

\section{References}

1. Belluco S, Patuzzi I, Ricci A. 2018. Bovine meat versus pork in Toxoplasma gondii transmission in Italy: a quantitative risk assessment model. International Journal of Food Microbiology, 269, 1-11.

2. Codaccioni C, Picone O, Lambert V, Maurice P, Pomar L, Winer N, Guibaud L, Lavergne RA, Saliou AH, Quinio D,
Benachi A, Noel C, Ville Y, Cuillier F, Pomares C, Ferret N, Filisetti D, Weingertner AS, Vequeau-Goua V, Cateau E, Benoist G, Wallon M, Dommergues M, Villena I, Mandelbrot L. 2020. Ultrasound features of fetal toxoplasmosis: A contemporary multicenter survey in 88 fetuses. Prenatal Diagnosis, 2, Online ahead of print. https://doi.org/10.1002/pd.5756.

3. Dabritz HA, Conrad PA. 2010. Cats and Toxoplasma: implications for public health. Zoonoses Public Health, 57(1), 34-52.

4. Darabus G, Hotea I, Oprescu I, Morariu S, Brudiu I, Olariu RT. 2011. Toxoplasmosis seroprevalence in cats and sheep from Western Romania. Revue de Médecine Vétérinaire, 162, 316.

5. Fanigliulo D, Marchi S, Montomoli E, Trombetta CM. 2020. Toxoplasma gondii in women of childbearing age and during pregnancy: seroprevalence study in Central and Southern Italy from 2013 to 2017. Parasite, 27, 2.

6. Flegr J, Prandota J, Sovičková M, Israili ZH. 2014. Toxoplasmosis-a global threat. Correlation of latent toxoplasmosis with specific disease burden in a set of 88 countries. PLoS One, 9(3), e90203.

7. Gargaté MJ, Ferreira I, Vilares A, Sarvi S, Amouei A, Shokri A, Rahimi MT, Hosseini SA, Daryani A. 2016. Toxoplasma gondii seroprevalence in the Portuguese population: comparison of three cross-sectional studies spanning three decades. BMJ Open, 2016(6), e011648.

8. Gebremedhin EZ, Abebe AH, Tessema TS, Tullu KD, Medhin G, Vitale M, Di Marco V, Cox E, Dorny P. 2013. Seroepidemiology of Toxoplasma gondii infection in women of child-bearing age in central Ethiopia. BMC Infectious Diseases, 13, 101.

9. Hussain MA, Stitt V, Szabo EA, Nelan B. 2017. Toxoplasma gondii in the Food Supply. Pathogens, 6(2), 21.

10. Jones JL, Kruszon-Moran D, Rivera HN, Price C, Wilkins PP. 2014. Toxoplasma gondii seroprevalence in the United States 2009-2010 and comparison with the past two decades. American Journal of Tropical Medicine and Hygiene, 90(6), $1135-1139$.

11. Lilly EL, Wortham CD. 2013. High prevalence of Toxoplasma gondii oocyst shedding in stray and pet cats (Felis catus) in Virqginia, United States. Parasites \& Vectors, 6, 266.

12. Mizani A, Alipour A, Sharif M, Sarvi S, Amouei A, Shokri A, Rahimi MT, Hosseini SA, Daryani A. 2017. Toxoplasmosis seroprevalence in Iranian women and risk factors of the disease: a systematic review and meta-analysis. Tropical Medicine and Health, 45, 7.

13. Montoya JG, Liesenfeld O. 2004. Toxoplasmosis. Lancet, 363, 1965-1976.

14. Nogareda F, Le Strat Y, Villena I, De Valk H, Goulet V. 2014. Incidence and prevalence of Toxoplasma gondii infection in women in France, 1980-2020: model-based estimation. Epidemiology and Infection, 142, 1661-1670.

15. Olariu TR, Darabus G, Cretu O, Jurovits O, Giura E, Erdelean V, Marincu I, Iacobiciu I, Petrescu C, Koreck A. 2008. Prevalence of Toxoplasma gondii antibodies among women of childbearing age in Timis County. Lucrări Stiintifice Medicină Veterinară Timisoara, 41, 367-371.

16. Olariu TR, Remington JS, McLeod R, Alam A, Montoya JG. 2011. Severe congenital toxoplasmosis in the United States: clinical and serologic findings in untreated infants. Pediatric Infectious Disease Journal, 30(12), 1056-1061.

17. Olariu TR, Petrescu C, Darabus G, Lighezan R, Mazilu O. 2015. Seroprevalence of Toxoplasma gondii in Western Romania. Infectious Diseases, 47(8), 580-583.

18. Olariu TR, Press C, Talucod J, Olson K, Montoya JG. 2019. Congenital toxoplasmosis in the United States: clinical and serologic findings in infants born to mothers treated during pregnancy. Parasite, 26, 13. 
19. Olariu TR, Ursoniu S, Hotea I, Dumitrascu V, Anastasiu D, Lupu MA. 2020. Seroprevalence and risk factors of Toxoplasma gondii infection in pregnant women from Western Romania. Vector Borne and Zoonotic Diseases, 20(10), 763-767.

20. Pappas G, Roussos N, Falagas ME. 2009. Toxoplasmosis snapshots: global status of Toxoplasma gondii seroprevalence and implications for pregnancy and congenital toxoplasmosis. International Journal for Parasitology, 39(12), 1385-1394.

21. Peyron F, Wallon M, Kieffer F, Garweg J. 2016. Toxoplasmosis, in Infectious Diseases of the Fetus and Newborn Infant, 7th edn, Remington JS, Klein JO, Wilson CB, Nizet V, Maldonado Y, Editors. Elsevier Saunders: Philadelphia, PA. p. 949-1042.

22. Pribakovic JA, Katanic N, Radevic T, Tasic MS, Kostic M, Stolic B, Radulovic A, Minic V, Bojovic K, Katanic R. 2019. Serological status of childbearing-aged women for Toxoplasma gondii and cytomegalovirus in northern Kosovo and Metohija. Revista da Sociedade Brasileira de Medicina Tropical, 52, e20170313.

23. Rostami A, Riahi SM, Gamble HR, Fakhri Y, Nourollahpour Shiadeh M, Danesh M, Behniafar H, Paktinat S, Foroutan M,
Mokdad AH, Hotez PJ, Gasser RB. 2020. Global prevalence of latent toxoplasmosis in pregnant women: a systematic review and meta-analysis. Clinical Microbiology and Infection, 26(6), 673-683.

24. Shapiro K, Bahia-Oliveira L, Dixon B, Dumètre A, de Wit LA, VanWormer E, Villena I. 2019. Environmental transmission of Toxoplasma gondii: oocysts in water, soil and food. Food and Waterborne Parasitology, 15, e00049.

25. Vilibic-Cavlek T, Ljubin-Sternak S, Ban M, Kolaric B, Sviben M, Mlinaric-Galinovic G. 2011. Seroprevalence of TORCH infections in women of childbearing age in Croatia. Journal of Maternal-Fetalal and Neonatal Medicine, 24(2), 280-283.

26. Wam EC, Sama LF, Ali IM, Ebile WA, Aghangu LA, Tume CB. 2016. Seroprevalence of Toxoplasma gondii IgG and IgM antibodies and associated risk factors in women of child-bearing age in Njinikom, NWCameroon. BMC Research Notes, 9, 406.

27. Wilking H, Thamm M, Stark K, Aebischer T, Seeber F. 2016. Prevalence, incidence estimations and risk factors of Toxoplasma gondii infection in Germany: a representative, cross-sectional, serological study. Scientific Reports, 6, 22551.

Cite this article as: Mihu AG, Balta C, Marti DT, Paduraru AA, Lupu MA \& Olariu TR. 2020. Seroprevalence of Toxoplasma gondii infection among women of childbearing age in an endemic region of Romania, 2016-2018. Parasite 27, 59.

\section{-0 PARASTE}

An international open-access, peer-reviewed, online journal publishing high quality papers on all aspects of human and animal parasitology

Reviews, articles and short notes may be submitted. Fields include, but are not limited to: general, medical and veterinary parasitology; morphology, including ultrastructure; parasite systematics, including entomology, acarology, helminthology and protistology, and molecular analyses; molecular biology and biochemistry; immunology of parasitic diseases; host-parasite relationships; ecology and life history of parasites; epidemiology; therapeutics; new diagnostic tools.

All papers in Parasite are published in English. Manuscripts should have a broad interest and must not have been published or submitted elsewhere. No limit is imposed on the length of manuscripts.

Parasite (open-access) continues Parasite (print and online editions, 1994-2012) and Annales de Parasitologie Humaine et Comparée (1923-1993) and is the official journal of the Société Française de Parasitologie. 